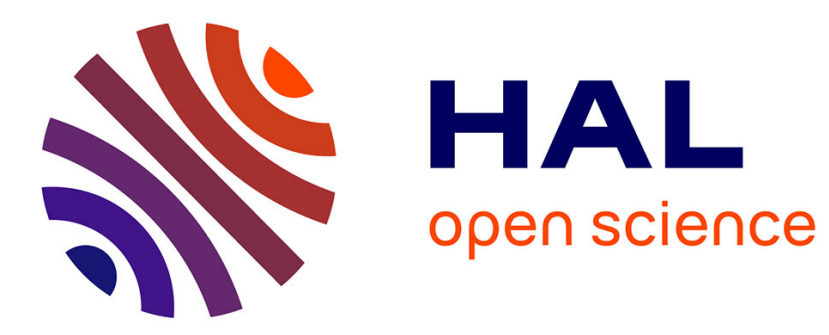

\title{
X-ray diffraction study of precipitation in melt-spun high speed steels
}

\author{
J. Härle, P. Lamparter, S. Steeb
}

\section{To cite this version:}

J. Härle, P. Lamparter, S. Steeb. X-ray diffraction study of precipitation in melt-spun high speed steels. Journal de Physique IV Proceedings, 1993, 03 (C8), pp.C8-307-C8-310. 10.1051/jp4:1993861 . jpa-00252292

\section{HAL Id: jpa-00252292 https://hal.science/jpa-00252292}

Submitted on 1 Jan 1993

HAL is a multi-disciplinary open access archive for the deposit and dissemination of scientific research documents, whether they are published or not. The documents may come from teaching and research institutions in France or abroad, or from public or private research centers.
L'archive ouverte pluridisciplinaire HAL, est destinée au dépôt et à la diffusion de documents scientifiques de niveau recherche, publiés ou non, émanant des établissements d'enseignement et de recherche français ou étrangers, des laboratoires publics ou privés. 


\title{
X-ray diffraction study of precipitation in melt-spun high speed steels
}

\author{
J. HÄRLE, P. LAMPARTER and S. STEEB
}

Max-Planck-Institut für Metallforschung, Institut für Werkstoffwissenschaft, Seestrasse 92, 70174 Stuttgart, Germany

\begin{abstract}
The high speed steels ASP30 and ASP60 were rapidly quenched from the melt using the melt spinning method. Their structure was investigated in the as-quenched state as well as in-situ during annealing at $560^{\circ} \mathrm{C}$ and $700^{\circ} \mathrm{C}$, respectively. The carbide precipitates were identified by wide angle $X$-ray diffraction. For the small angle $X$-ray scattering measurements (down to $Q_{\min }=2 \times 10^{-3} \AA^{-1}$ ) a laboratory-built pin hole instrument, equipped with a furnace and a 2-dimensional detector, was used. Slowly growing $\mathrm{M}_{6} \mathrm{C}$-carbides are the dominant precipitates. Rapidly growing $\mathrm{MC}$-carbides are present in ASP60 with a smaller fraction, but no $\mathrm{M}_{2} \mathrm{C}$-carbides develop. The coarsening of the precipitates saturates at long annealing times. The Johnson-Mehl-Avrami analysis of the evolution of the volume fraction of $M_{6} \mathrm{C}$ in ASP 60 indicates a transition in the precipitation kinetics.
\end{abstract}

\section{INTRODUCTION}

The high speed steels ASP30 ( $\left.\mathrm{Fe}_{74.0} \mathrm{Co}_{7.6} \mathrm{Cr}_{4.3} \mathrm{Mo}_{2.9} \mathrm{~W}_{1.8} \mathrm{~V}_{3.4} \mathrm{C}_{6.1}\right)$ and ASP60

$\left(\mathrm{Fe}_{62.4} \mathrm{Co}_{9.8} \mathrm{Cr}_{4.2} \mathrm{Mo}_{4.0} \mathrm{~W}_{2.0} \mathrm{~V}_{7.0} \mathrm{C}_{10.6}\right)$ contain carbide forming elements at relatively high concentrations. Depending on the history of the production of the material the carbides $\mathrm{MC}, \mathrm{M}_{2} \mathrm{C}$, $\mathrm{M}_{6} \mathrm{C}, \mathrm{M}_{7} \mathrm{C}_{3}$, and $\mathrm{M}_{23} \mathrm{C}_{6}$ are formed which are embedded in a ferrite (bcc), an austenite (fcc), and/or a martensitic (tetragonal) matrix phase. MC contains mainly $V$ and Mo as carbide formers, $\mathrm{M}_{2} \mathrm{C}$ mainly Mo and $\mathrm{Cr}$, and $\mathrm{M}_{6} \mathrm{C}$ mainly $\mathrm{W}$, Mo and $\mathrm{Fe}(\mathrm{M}=$ metal) $[1,2]$.

For the present study on the melt-spun high speed steels ASP30 and ASP60 a pinhole small angle $\mathrm{X}$-ray scattering (SAXS) camera was developed [3].

\section{WIDE ANGLE DIFFRACTION}

Using a wide angle X-ray diffractometer equipped with a furnace and a position-sensitive detector the phase transformations in the high speed steels during heat treatments were observed in-situ.

\section{ASP30}

The diffraction diagram of melt-spun ASP30 showed mainly the fcc $\gamma$-austenite phase with a small fraction of the bec $\alpha$-ferrite phase. Primary carbides were not detected by wide angle diffraction. Figure 1a displays the phase transformations during annealing at $700^{\circ} \mathrm{C}$. The $\gamma$-austenite phase dissolves rapidly within the first few hours. Secondary $\mathrm{M}_{6} \mathrm{C}$ carbides occur with gradually increasing fraction. The bump near $\mathrm{d}=2.4 \AA$ indicates a small fraction of $\mathrm{MC}$ carbides. $\mathrm{No}_{2} \mathrm{C}$ carbides are found in the annealed ASP30 specimens, whereas in conventional ASP high speed steels MC and $\mathrm{M}_{2} \mathrm{C}$ precipitates were detected [1,2]. 


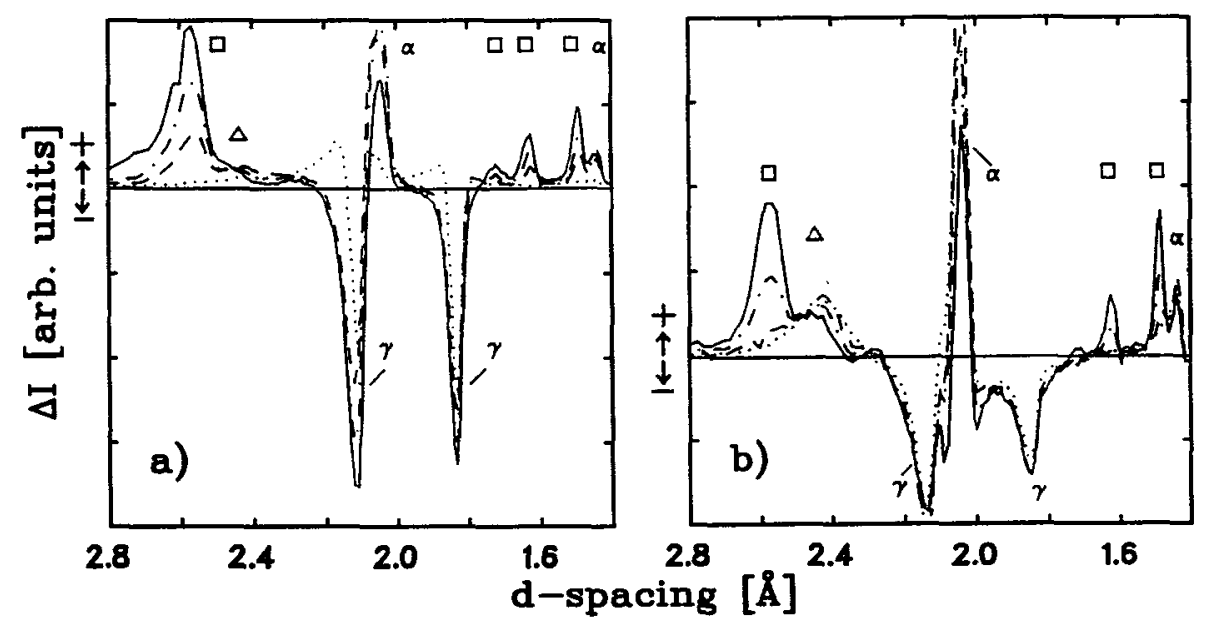

Fig. 1: Wide angle $X$-ray diffraction. a) ASP30, b) ASP60. Change of diffracted intensity $\Delta I$ versus $d$-spacing during annealing at $700^{\circ} \mathrm{C} .(\cdots) 1 \mathrm{~h},(--) 24 \mathrm{~h},(-\cdot-) 48 \mathrm{~h},(-) 96 \mathrm{~h}$. () $\mathrm{M}_{6} \mathrm{C},(\Delta) \mathrm{MC}$.

\section{ASP60}

As-quenched ASP 60 consists mainly of bcc $\alpha$-ferrite. Besides this a small amount of fec $\gamma$-austenite was found whose d-spacing is somewhat enlarged due to the high supersaturation. Some samples showed the presence of primary MC carbides. It was found that this contribution depends strongly on the cooling conditions. Increasing the quench rate of the melt-spinning process suppressed the precipitation of primary MC carbides. At the same time the formation of $\gamma$-austenite was favoured.

Figure $2 \mathrm{~b}$ shows the annealing diagrams at $700^{\circ} \mathrm{C}$ of a specimen which did not contain $\mathrm{MC}$ carbides in the as-quenched state. The disintegration of the $\gamma$-phase is completed within the first hour, whereas the $\alpha$-phase stabilizes. Secondary MC carbides develop rapidly without further increase at long annealing times. Secondary $\mathrm{M}_{6} \mathrm{C}$ carbides form gradually at longer annealing times. No $\mathrm{M}_{2} \mathrm{C}$ carbides were detected with wide angle diffraction in the present study. In powder metallurgical ASP60 extremely fine $\mathrm{M}_{2} \mathrm{C}$ secondary precipitates were found [1].

\section{SMALL ANGLE SCATTERING}

A pinhole camera was constructed which consists of a $12 \mathrm{~kW}$ rotating-anode, a graphite monochromator, a specimen vacuum chamber with a computer controlled furnace, and a two-dimensional position-sensitive X-ray detector [3]. Using $\mathrm{Mo}_{\mathbf{0}}-\mathrm{K}_{\alpha}-$ as well as $\mathrm{Cr}-\mathrm{K}_{\alpha}$-radiation the range $2.5 \times 10^{-3} \AA^{-1} \leq Q \leq 0.3 \AA^{-1}$ of the scattering vector $Q$ was covered. The samples were measured in the as-quenched state and in-situ during annealing at $560^{\circ} \mathrm{C}$ and $700^{\circ} \mathrm{C}$, respectively. For the conversion of the measured intensities into absolute scattering units a calibrated reference sample was used (aluminium Al-8 [4]).

\subsection{ASP 30}

Figure $2 \mathrm{a}$ shows as Guinier plots the SAXS curves from an as-quenched sample and after a $92 \mathrm{~h}$ anneal at $560^{\circ} \mathrm{C}$. The increase of $\mathrm{I}(Q)$ in the entire $Q$-range is due to the formation of secondary precipitates. An overview over all measured curves suggested the presence of two Guinier regimes according to a distribution of the pricipitates with accumulation around two sizes $R 1$ and $R 2$. Both radii increase with the time of anneal and reach a maximum plateau after about 50 hours with $R 1 \approx 100 \AA$ and $R 2 \approx 150 \AA$ (Fig.3a). 


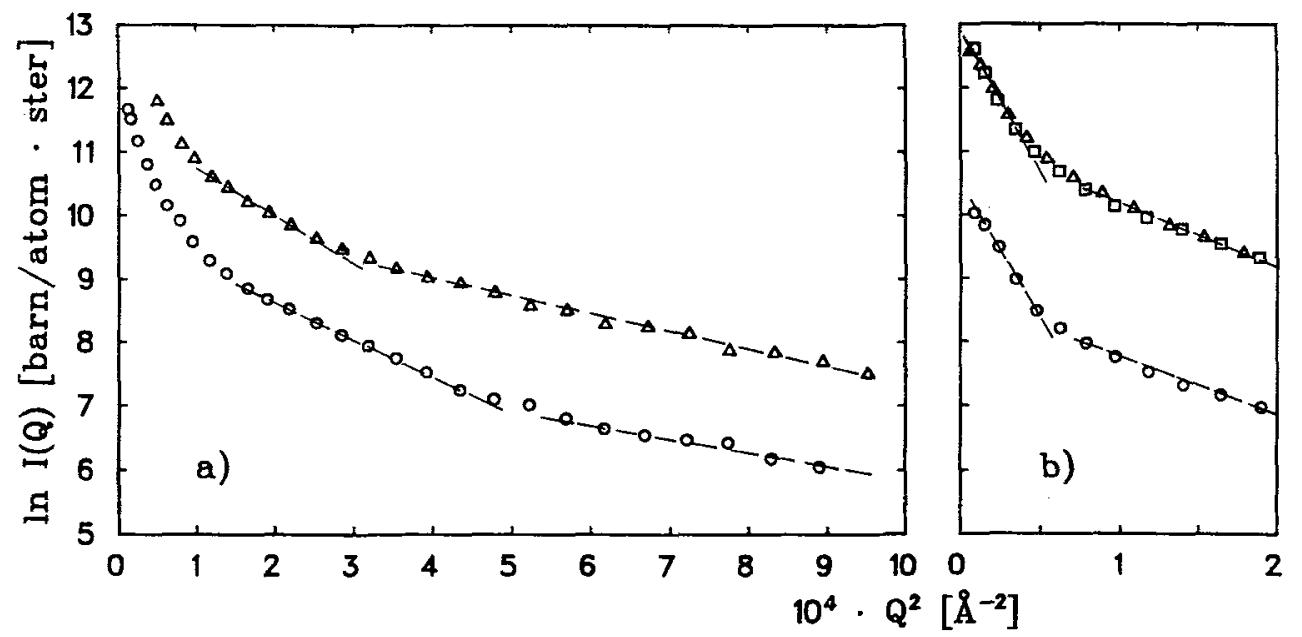

Fig. 2: $\quad$ Small angle $X$-ray diffraction. Guinier plot, $\left(---^{-}\right)$linear fit.

a) ASP30, (o) as-quenched, ( $\triangle) 560^{\circ} \mathrm{C} / 92 \mathrm{~h}$, b) ASP60,

(o) as-quenched, $(\Delta) 560^{\circ} \mathrm{C} / 72 \mathrm{~h},(\square) 700^{\circ} \mathrm{C} / 72 \mathrm{~h}$.

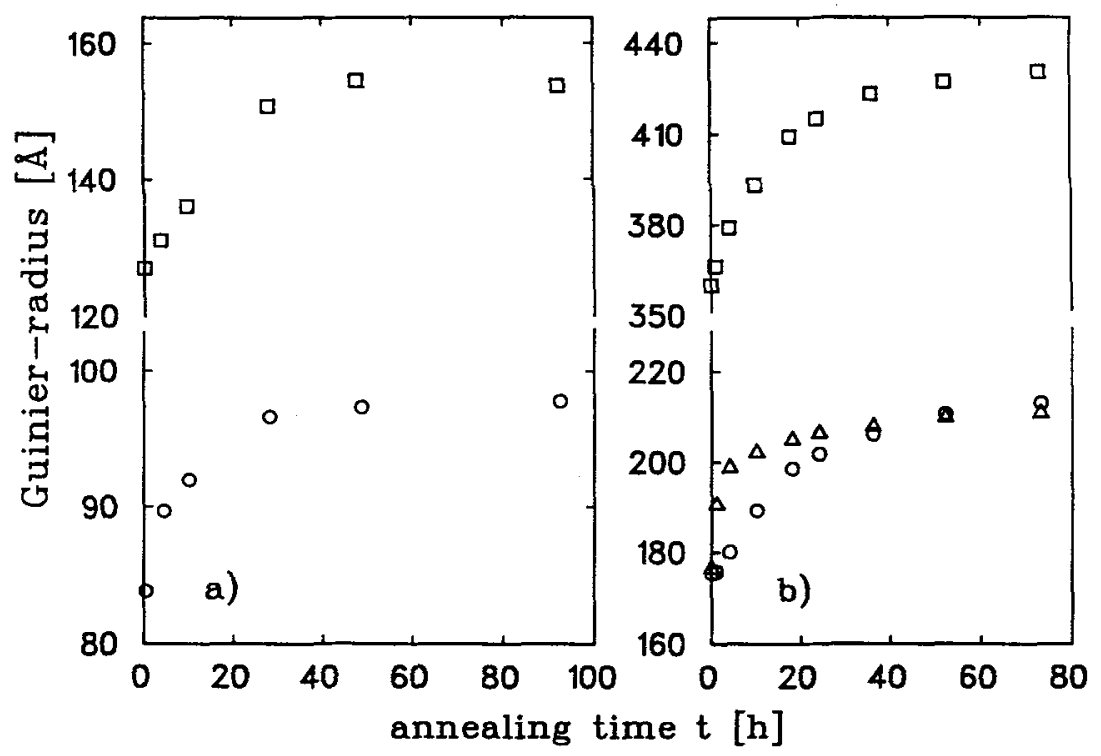

Fig. 3: Guinier radii. a) ASP30, $560^{\circ} \mathrm{C}$ (o) $R 1$, (a) $R 2$, b) ASP60,

(o) $R 1,560^{\circ} \mathrm{C},(\Delta) R 1,700^{\circ} \mathrm{C}$, () $R 2,560^{\circ} \mathrm{C}$.

\subsection{ASP60}

Figure $2 \mathrm{~b}$ shows the Guinier plots for the as-quenched state and after annealing for 72 hours at $560^{\circ} \mathrm{C}$ and $700^{\circ} \mathrm{C}$, respectively. Apparently the ASP60 sample attains the same state at both temperatures. Again a systematic overview of the bulk of SAXS curves suggested the existence of two Guinier regimes.

Figure $3 \mathrm{~b}$ shows the radii $\mathrm{R} 1$ and $\mathrm{R} 2$ for $560^{\circ} \mathrm{C}$ and $\mathrm{R} 1$ for $700^{\circ} \mathrm{C}$. The sizes of the precipitates increase up to a value of $R 1 \approx 210 \AA$ for the smaller and $R 2 \approx 430 \AA$ for the larger ones. At the higher temperature, $700^{\circ} \mathrm{C}, R 1$ increases faster, but saturates at the same level as at $560^{\circ} \mathrm{C}$. 


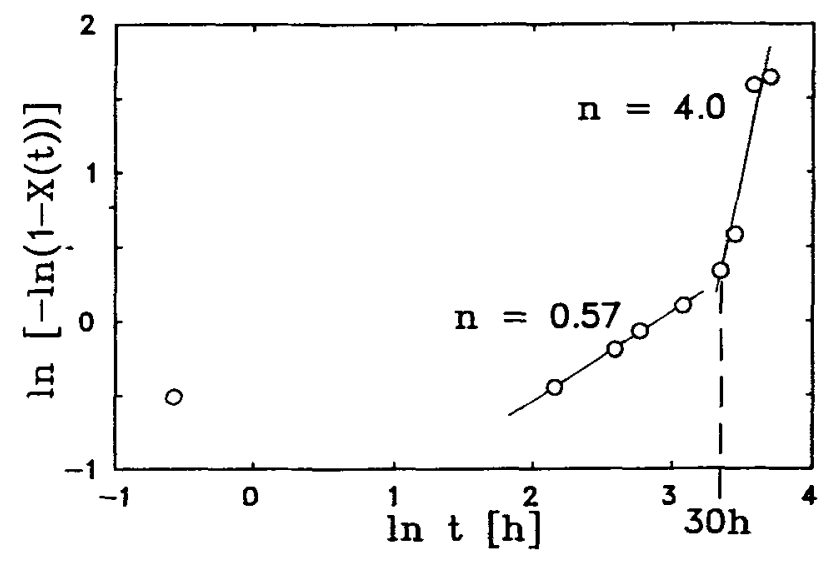

Fig. 4: JMA plot of the normalized volume fraction $x(t)$ of $\mathrm{M}_{6} \mathrm{C}$ precipitates versus the annealing time $t$.

As shown by wide angle diffraction, ASP60 consists mainly of the $\alpha-\mathrm{Fe}$ matrix and $\mathrm{M}_{6} \mathrm{C}$ secondary precipitates. Furthermore, $\gamma-\mathrm{Fe}$ as well as MC carbides exhibit only a small difference of the electron density against $\alpha-\mathrm{Fe}$ in comparison with $\mathrm{M}_{6} \mathrm{C}$ carbides. For the numerical values of the electron densities of the involved phases and for the compositions of the carbides we refer to the detailed considerations in ref. [3]. On the base that ASP60 can be treated as a two-phase system, $\alpha-\mathrm{Fe}+$ $M_{6} C$, the volume fraction of the $M_{6}$ C precipitates $w_{p}$ was calculated from the integrated intensity [5] with the result that the as-quenched ASP60 specimen contained a fraction of $2 \% \mathrm{M}_{6} \mathrm{C}$ carbides which increased during annealing at $700^{\circ} \mathrm{C}$ up to a content of $10 \%$.

With the JMA theory [6] the growth of a precipitated phase can be described as $x(t)=1-\exp \left[-(K t)^{\mathbf{n}}\right]$

where $x(t)=w_{\mathrm{p}}(t) / w_{\mathrm{p}}(t=\infty)=$ normalized volume fraction, $K=$ reaction constant, $n=\mathrm{JMA}$ exponent. The JMA exponent depends on the kinetics of the process and can be written in terms of three parameters: $n=a+b \cdot m$, where $a=$ nucleation parameter $(=0$ for preformed nuclei $=1$ for constant, $>1$ for increasing, $0<1$ for decreasing nucleation rate), $b=$ dimension of growth, $m=$ type of growth ( $=1$ linear with time, $=0.5$ parabolic).

The JMA plot of the normalized volume fraction of the $\mathrm{M}_{6} \mathrm{C}$ precipitates in Fig. 4 shows two regimes. A first one where $n=0.57$. This value implies the combination $a=0, b=1 m=0.5$ indicating parabolic growth of the carbides from preformed nuclei. The second regime yields $n=4.0$, corresponding to the combination $a=1, b=3, m=1$. This points to a constant nucleation rate and 3-dimensional growth linear with time.

Acknowledgement

Thanks are due to Deutsche Forschungsgemeinschaft for financial support.

\section{References}

[1] K. Stiller, L. -E. Svensson, P.R. Howell, Wang Rong, H.-O. Andrén, G.L. Dunlop, Acta Met. 32 (1984) 1457.

[2] H.F. Fischmeister, S. Karagöz, H, -O. Andrén, Acta Met. 36 (1988) 817.

[3] J. Härle, Thesis, University Stuttgart (1990).

[4] The Al-8 sample was made available from the Oak Ridge Nat. Lab., USA.

[5] A. Guinier, G. Fournet, Small Angle Scattering of X-Rays, Wiley \& Sons, London (1955).

[6] W.A. Johnson, K.F. Mehl, Trans. Am. Inst. Mining Met. Engns. 135 (1981) 315, and references there. 